\title{
Anurans in a forest remnant in the transition zone between cerrado and atlantic rain forest domains in southeastern Brazil
}

\author{
RENATA M. PIRANI ${ }^{1}$, LUCIANA B. NASCIMENTO ${ }^{2}$ and RENATO N. FEIO ${ }^{1}$ \\ ${ }^{1}$ Departamento de Biologia Animal, Museu de Zoologia João Moojen, \\ Vila Gianetti, 32, Universidade Federal de Viçosa, 36570-000 Viçosa, MG, Brasil \\ ${ }^{2}$ Programa de Pós-graduação em Zoologia de Vertebrados, Museu de Ciências Naturais, \\ Pontifícia Universidade Católica de Minas Gerais, 30535-610 Belo Horizonte, MG, Brasil
}

Manuscript received on June 25, 2012; accepted for publication on November 13, 2012

\begin{abstract}
This study presents the species richness, temporal distribution and reproductive activity of anurans from the Uaimií State Forest (Floresta Estadual do Uaimií - FLOE Uaimií), situated in the Quadrilátero Ferrífero region, municipality of Ouro Preto, Minas Gerais state, Brazil. Field activities were performed monthly from September 2009 to August 2010. We recorded 36 anurans species, distributed in 10 families. The greatest richness of the sampled sites corresponds to a permanent rivulet in a secondary forest. The majority of anuran species presented seasonal vocalization activity pattern, mainly in the rainy season. The anuran species composition of FLOE Uaimií is similar to others studied areas from the Quadrilátero Ferrífero region.
\end{abstract}

Key words: amphibians, Espinhaço Mountain Range, inventory, reproductive activity.

\section{INTRODUCTION}

Communities can be seen as units determined by biotic interactions (Pianka 1973). In anurans communities, several strategies are used allowing many species to coexist within the same environment (Cardoso and Haddad 1992). Among these strategies, there are differences in the use of breeding (RossaFeres and Jim 1994, Conte and Rossa-Feres 2007) and calling sites (Cardoso et al. 1989), preferences for activities in different seasons (Cardoso and Haddad 1992, Eterovick and Sazima 2000, Conte and RossaFeres 2006), or for activities at different times of the day (Cardoso and Haddad 1992). These differences can be interpreted as mechanisms of pre-zygotic reproductive isolation (Wells 1977).

Correspondence to: Renata Magalhães Pirani

E-mail: renatampirani@gmail.com
Brazil presents a great diversity of geographical reliefs, among them are the mountain ranges of Espinhaço and Mantiqueira, in eastern Brazil. The Espinhaço Mountain Range (hereafter called EMR) corresponds to a transition between two domains, the Cerrado and the Atlantic Forest, and is the largest rocky meadow formation in Brazil, considered by some authors as another domain (Gontijo 2009). The EMR covers an area of approximately three million hectares and its geographical range beginning in the south in the municipality of Ouro Preto, Minas Gerais state, extending northwards to the municipality of Jacobina, in Bahia state (Gontijo 2009). The north portion of the Mantiqueira Mountain Range (hereafter called MMR) connects with the plateaus and hills of the EMR through an elevated region, 
which joins Serra do Ibitipoca (situated in MMR) to the meridional portion of the Espinhaço, making it difficult to establish the precise limits between them (Cruz and Feio 2007).

The Quadrilátero Ferrífero region, at Minas Gerais state, is included in south portion of in EMR (Gontijo 2009) and comprises the mountain ranges of Caraça, Curral, Piedade, Itacolomi, Itabirito, Ouro Branco, and Moeda (Viana and Filgueiras 2009). The region is known for the iron ore richness and, consequently, for intense mining activities that modify the natural landscape (Silvano and Segalla 2005). Besides, the Quadilátero Ferrífero region is considered a priority area for amphibian conservation in Minas Gerais state. The main current threat to amphibian populations at this region is the natural habitat destruction by deforestation, due to urban, agricultural and mining activities (Silvano and Segalla 2005). Faced with these threats, one of the recommendations to protect this region is scientific research (Drummond et al. 2005).

Among the studies conducted in Minas Gerais state involving reproductive activity and/or frogs communities, Nascimento et al. (1994), Eterovick and Sazima (2000), Pedralli et al. (2001), Eterovick (2003), Eterovick and Sazima (2004), Nascimento et al. (2005), Canelas and Bertoluci (2007), São Pedro and Feio $(2010,2011)$ in the EMR; Cruz et al. (2009), Lacerda et al. (2009), and Moura et al. (2012) in the MMR can be highlighted. EMR and MMR have been showing a high endemism rate which needs the development of long-term studies for understanding their biogeographical patterns (Cruz and Feio 2007).

According to the context given above, the present study shows data on the species richness and temporal distribution of an anuran community in Uaimií State Forest (Floresta Estadual do Uaimií - FLOE Uaimií), a conservation unit in the municipality of Ouro Preto, at Quadrilátero Ferrifero region, at Minas Gerais state, with comments on the biogeography of southeastern region of Brazil. Additionally, it describes the annual reproductive activity patterns, based mainly on vocalization activity.

\section{MATERIALS AND METHODS}

STUDY AREA

The FLOE Uaimií $\left(20^{\circ} 29^{\prime} 66^{\prime \prime} \mathrm{S}, 4^{\circ} 57^{\prime} 47^{\prime \prime} \mathrm{W}\right.$, Figure 1) comprises an area of approximately 4,400 ha. located in the municipality of Ouro Preto, Minas Gerais state, at Quadrilátero Ferrífero region, in the southern portion of the Espinhaço mountain range (Alvarenga et al. 1997, IEF 2008). The conservation unit has typical vegetation of the transition between the Cerrado and Atlantic Forest morphoclimatic domains, with the occurrence of rocky meadows (campos rupestres) at the highest elevations, with altitudes ranging from 900 to 1,400 metres. It is the main source water source of the Rio das Velhas, the largest tributary of the São Francisco River Basin (IEF 2008).

The climate class of the study region is Cwa (sensu Köppen 1918) comprising a rainy season that occurs from October to March, with a monthly average of more than $110 \mathrm{~mm}$, accounting for approximately $81.5 \%$ of the total annual average at $1,373 \mathrm{~mm}$. The dry season is from April through September, during which the average rainfall is $42 \mathrm{~mm}$ per month (Sá Junior et al. 2011).

\section{FIELD ACTIVITIES}

Expeditions to study the anurans temporal distribution were performed monthly, lasting five days from September 2009 to August 2010. The temporal distribution study was conducted at four sites: two permanent rivulets (named Riacho do Alojamento - R1 - and the Cachoeira de São Bartolomeu -R2), one permanent pond (Brejo da Estrada - P1) and one temporary pond (Brejo do Campo Rupestre - P2). The areas were chosen based on their potential to host anuran species and also for easy access (Table I). 


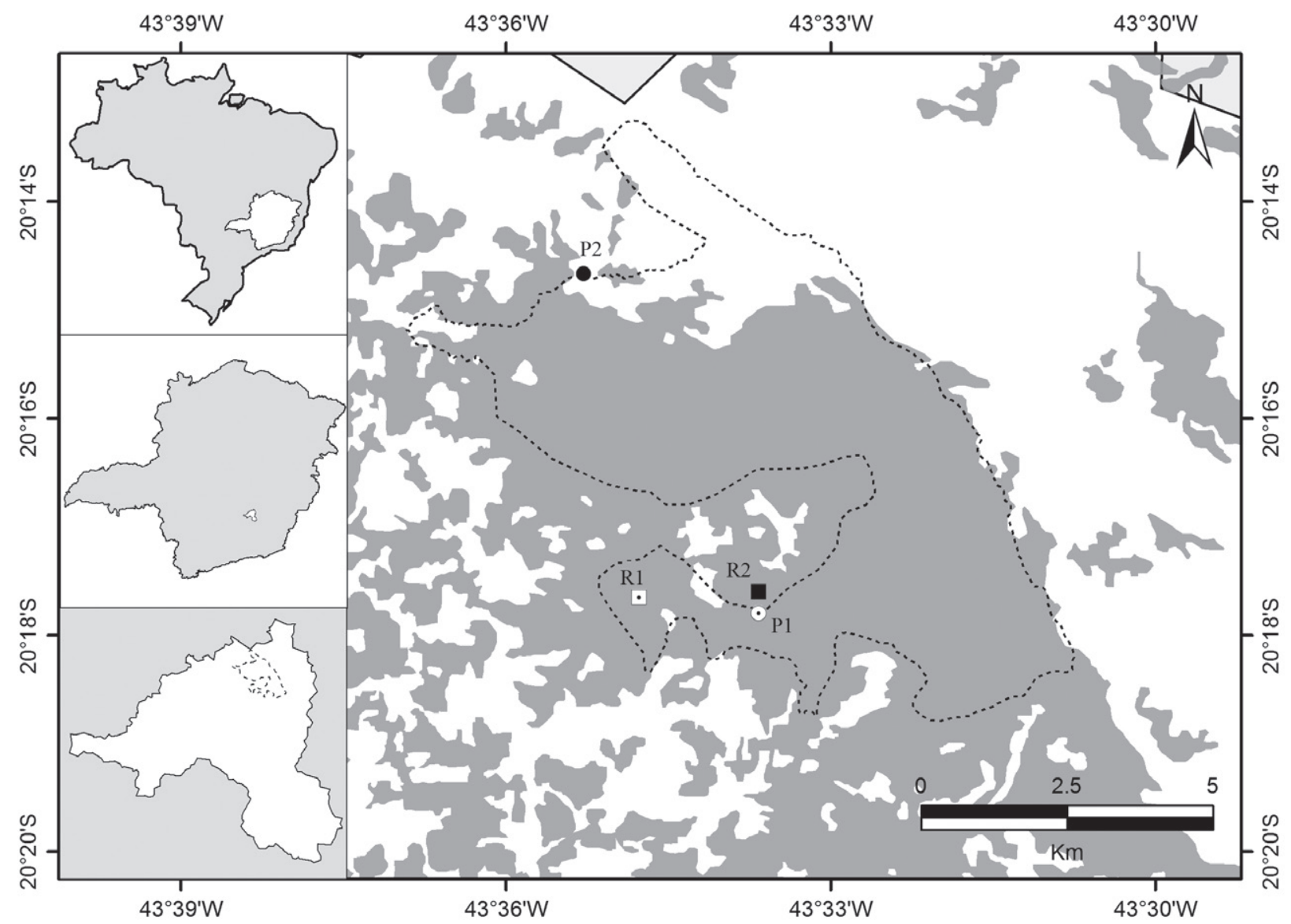

Figure 1 - Map of the sampled sites of the study showing the temporal distribution at FLOE Uaimií (Ouro Preto, MG): Riacho do Alojamento (R1); Cachoeira de São Bartolomeu (R2); Brejo da Estrada (P1); Brejo do Campo Rupestre (P2).

TABLE I

Sample sites for the study of temporal distribution characterization of the anuran communities in the FLOE Uaimií (Ouro Preto, MG) from September 2009 to August 2010.

\begin{tabular}{|c|c|c|c|}
\hline Sampled sites & Coordinates & Height & Description \\
\hline $\begin{array}{l}\text { R1 - Riacho do } \\
\text { alojamento }\end{array}$ & $\begin{array}{l}20^{\circ} 17^{\prime} 39 " \mathrm{~S} \\
43^{\circ} 34^{\prime} 46^{\prime \prime} \mathrm{W}\end{array}$ & $1,077 \mathrm{~m}$ & $\begin{array}{l}100 \mathrm{~m} \text { transect on a permanent rivulet in an area of secondary forest, } \\
\text { surrounded by trees and shrubs on the banks }\end{array}$ \\
\hline $\begin{array}{l}\text { R2- Cachoeira de } \\
\text { São Bartolomeu }\end{array}$ & $\begin{array}{l}20^{\circ} 17^{\prime} 39^{\prime \prime} \mathrm{S} \\
43^{\circ} 33^{\prime} 71^{\prime \prime} \mathrm{W}\end{array}$ & $1,080 \mathrm{~m}$ & $\begin{array}{l}50 \mathrm{~m} \text { transect on a permanent rivulet with waterfalls and a sequent pond in } \\
\text { secondary forest, surrounded by trees and shrubs on the banks }\end{array}$ \\
\hline $\begin{array}{l}\text { P1 - Brejo da } \\
\text { estrada }\end{array}$ & $\begin{array}{l}20^{\circ} 29^{\prime} 71^{\prime \prime} \mathrm{S} \\
43^{\circ} 56^{\prime} 05^{\prime \prime} \mathrm{W}\end{array}$ & $1,015 \mathrm{~m}$ & $\begin{array}{c}100 \mathrm{~m} \text { transect on a permanent enlarged water body in a secondary forest, } \\
\text { surrounded by grasses and shrubs on the edge }\end{array}$ \\
\hline $\begin{array}{l}\text { P2 - Brejo do } \\
\text { Campo Rupestre }\end{array}$ & $\begin{array}{l}20^{\circ} 14^{\prime} 40^{\prime \prime} \mathrm{S} \\
43^{\circ} 35^{\prime} 17^{\prime \prime} \mathrm{W}\end{array}$ & $1,147 \mathrm{~m}$ & $\begin{array}{l}\text { An approximate } 200 \mathrm{~m} \text { transect in a temporary swamp rocky meadow, with } \\
\text { sand and quartzitic rocks, surrounded by shrubs and grasses on the banks }\end{array}$ \\
\hline
\end{tabular}

Direct visualisations of individuals and/or zoophony were used for recording the species. Reproductive activity evidence was recorded considering the following parameters: a) couples in amplexus; b) mature females identified by visualization of oocytes through abdominal transparency; c) clutches; d) tadpoles and e) froglets.

The vocalization patterns of anuran species at FLOE Uaimií were defined as: (1) continuous: for species that vocalize, or for more than nine 
months of the study; (2) rainy season: for species with calling activity associated with the rainy months; (3) dry season: vocalization associated with the dry months; (4) opportunistic: for species that vocalized only after rains; and (5) not defined: species for which it was not possible to define a pattern (adapted from Bertoluci 1998, Bertoluci and Rodrigues 2002, Canelas and Bertoluci 2007, São Pedro and Feio 2010).

For the species inventory, data collected at other sampling sites in FLOE Uaimií and from other campaigns in the area were used. The data for accumulated rainfall in the region were provided by Área de Controle Ambiental from the company Novelis do Brasil LTDA, located in the municipality of Ouro Preto, Minas Gerais state, around 13 km from FLOE Uaimií. The air temperature at each site was measured at the beginning and the end of each night during observation activities. Its average was used as the month's temperature.

\section{DATA ANALYSIS}

The taxonomic nomenclature used in the present study is according to Pyron and Wiens (2011).

The Sorensen index (Krebs 1999) was used to verify the similarity in anurans species composition at FLOE Uaimií to the following mountain regions of south-central and south-eastern Minas Gerais state: Serra do Ouro Branco (São Pedro and Feio 2011), Parque Estadual do Itacolomi and Estação Ecológica do Tripuí (PE Itacolomi/EE Tripuí) (Pedralli et al. 2001), Parque Nacional Serra do Cipó (PARNA Cipó) (Eterovick and Sazima 2004), Reserva Particular do Patrimônio Nacional da Serra do Caraça (RPPN Serra do Caraça) (Canelas and Bertoluci 2007), in the EMR; and Parque Estadual da Serra do Brigadeiro (PESB) (Moura et al. 2012), Parque Estadual do Ibitipoca (PE Ibitipoca) (Cruz et al. 2009), and Parque Nacional da Serra do Caparaó (PARNA Caparaó) (V.K. Verdade et al. unpublished data), in the MMR. A cluster analysis by the unweighted average method (UPGMA) (Krebs,
1999) was performed to determine the existence of locations with similar species composition. The clusters were defined at a level with at least $40 \%$ similarity. For this analysis we considered only taxa with confirmed specific identity.

Voucher specimens, collected under the licenses IBAMA $n^{\circ}$ 20724-1 and IEF $n^{\circ}$ 055/09, were deposited in the collection of Amphibians in the Museu de Zoologia João Moojen, Universidade Federal de Viçosa (MZUFV), Viçosa, Minas Gerais state, Brazil.

\section{RESULTS}

We recorded 36 anurans species in FLOE Uaimií, distributed in 10 families: Brachycephalidae (2 species), Bufonidae (2), Centrolenidae (1), Craugastoridae (1), Odontophrynidae (2), Hylidae (19), Hylodidae (1), Leiuperidae (2), Leptodactylidae (5) and Microhylidae (1). The sample site P1 presented the highest richness (14 species), while the P2 and R1 sites had the lowest, with only seven species in each one (Figure 2).

The family Hylidae was the most representative, with a total of 19 species (51\%), and two that were unidentified, Bokermannohyla sp. (gr. circumdata) and Scinax sp. (aff. perereca). The last one corresponds to a species that is in the description process (L.B. Nascimento unpublished et al., data).

The Figure 3 presents the vocalization patterns displayed by the recorded anuran species. They were associated with the following patterns: 1) continuous: Aplastodiscus arildae and Hypsiboas polytaenius; 2) rainy season: Ischnocnema izecksohni, I. juipoca, Vitreorana uranoscopa, Aplastodiscus cavicola, Phyllomedusa burmeisteri, Scinax sp. (aff. perereca), Physalaemus cuvieri, Pseudopaludicola serrana, Leptodactylus cunicularius, L. furnarius, and L. fuscus; 3) dry season: Scinax luizotavioi; 4) opportunistic: Proceratophrys boiei; and 5) not defined: Rhinella pombali, $R$. rubescens, Haddadus binotatus, Bokermannohyla sp. (gr. 


\begin{tabular}{|c|c|c|c|c|c|}
\hline \multirow{2}{*}{ Family } & \multirow{2}{*}{ Species } & \multicolumn{4}{|c|}{ Collection sites } \\
\hline & & R1 & $\mathbf{R 2}$ & P1 & $\mathbf{P 2}$ \\
\hline \multirow{2}{*}{ Brachycephalidae } & Ischnocnema izecksohni (Caramaschi and Kisteumacher, 1989 "1988") & $\mathrm{x}$ & $\mathrm{x}$ & $\mathrm{x}$ & \\
\hline & Ischnocnema juipoca (Sazima \& Cardoso, 1978) & & & & $\mathrm{x}$ \\
\hline \multirow{2}{*}{ Bufonidae } & Rhinella pombali (Baldissera-Jr, Caramaschi \& Haddad, 2004) & $\mathrm{x}$ & $\mathrm{x}$ & $\mathrm{x}$ & $\mathrm{x}$ \\
\hline & Rhinella rubescens (A. Lutz, 1925) & & & & $\mathrm{x}$ \\
\hline Centrolenidae & Vitreorana uranoscopa (Müller, 1924) & $\mathrm{x}$ & & $\mathrm{x}$ & \\
\hline Craugastoridae & Haddadus binotatus (Spix, 1824) & $\mathrm{x}$ & & $\mathrm{x}$ & \\
\hline \multirow{2}{*}{ Odontophrynidae } & Odontophrynus cultripes Reinhardt \& Lütken, 1861"1862" * & & & & \\
\hline & Proceratophrys boiei (Wied-Neuwied, 1825) & & $\mathrm{x}$ & $\mathrm{x}$ & \\
\hline \multirow{19}{*}{ Hylidae } & Aplastodiscus arildae (Cruz \& Peixoto, 1987 "1985") & $\mathrm{x}$ & & $\mathrm{x}$ & \\
\hline & Aplastodiscus cavicola (Cruz \& Peixoto, 1985 "1984") & & $\mathrm{x}$ & & \\
\hline & Bokermannohyla sp. (gr. circumdata) & $\mathrm{x}$ & $\mathrm{x}$ & $\mathrm{x}$ & \\
\hline & Bokermannohyla nanuzae (Bokermann \& Sazima, 1973) * & & & & \\
\hline & Bokermannohyla martinsi (Bokermann, 1964) * & & & & \\
\hline & Dendropsophus elegans (Wied-Neuwied, 1824) * & & & & \\
\hline & Dendropsophus minutus (Peters, 1872) & & $\mathrm{x}$ & & \\
\hline & Hypsiboas albopunctatus (Spix, 1824) & & $\mathrm{x}$ & & \\
\hline & Hypsiboas faber (Wied-Neuwied, 1821) & & $\mathrm{x}$ & & \\
\hline & Hypsiboas pardalis (Spix, 1824)* & & & & \\
\hline & Hypsiboas polytaenius (Cope, 1870"1869") & & $\mathrm{x}$ & & \\
\hline & Phasmahyla jandaia (Bokermann \& Sazima, 1978) & & & $\mathrm{x}$ & \\
\hline & Phyllomedusa burmeisteri Boulenger, 1882 & & $\mathrm{x}$ & & \\
\hline & Phyllomedusa ayeaye (Lutz, 1966)* & & & & \\
\hline & Scinax sp. (aff. perereca) & & $\mathrm{x}$ & & \\
\hline & Scinax longilineus * (B. Lutz, 1968) & & & & \\
\hline & Scinax curicica Pugliese, Pombal \& Sazima, $2004 *$ & & & & \\
\hline & Scinax fuscovarius (A. Lutz, 1925) * & & & & \\
\hline & Scinax luizotavioi (Caramaschi \& Kisteumacher, 1989) & $\mathrm{x}$ & $\mathrm{x}$ & & \\
\hline Hylodidae & Hylodes babax Heyer, $1982 *$ & & & & \\
\hline \multirow{2}{*}{ Leiuperidae } & Physalaemus cuvieri Fitzinger, 1826 & & $\mathrm{x}$ & & \\
\hline & Pseudopaludicola serrana (Toledo, 2010) & & & & $\mathrm{x}$ \\
\hline \multirow{5}{*}{ Leptodactylidae } & Leptodactylus cunicularius Sazima \& Bokermann, 1978 & & & & $\mathrm{x}$ \\
\hline & Leptodactylus furnarius Sazima \& Bokermann, 1978 & & & & $\mathrm{x}$ \\
\hline & Leptodactylus fuscus (Schneider, 1799) & & & & $\mathrm{x}$ \\
\hline & Leptodactylus sertanejo Giaretta \& Costa, 2007* & & & & \\
\hline & Leptodactylus latrans (Steffen, 1815) * & & & & \\
\hline Microhylidae & Elachistocleis cesarii (Schneider, 1799) & & $\mathrm{x}$ & & \\
\hline Total & 36 species & (7) & (14) & (8) & (7) \\
\hline
\end{tabular}

Figure 2 - List of amphibians species and the habitat where they occurred: Riacho do Alojamento (R1); Cachoeira do Bartlomeu (R2); Brejo da Estrada (P1); Brejo do Campo Rupestre (P2). * Species recorded outside the monitored environments, in FLOE Uaimií (Ouro Preto, MG). 
circumdata), Dendropsophus minutus, Hypsiboas albopunctatus, and $H$. faber. The species Phasmahyla jandaia and Elachistocleis cesarii could not be placed in any of the defined patterns since they were not observed vocalizing. The species Phasmahyla jandaia was recorded only in February and a young of E. cesarii was recorded only in October. Although Bokermannohyla sp. (gr. circumdata) was placed in the not defined vocalization pattern, mature females were observed in October and January, a male was observed vocalizing in February and soon after (May and June), tadpoles and froglets were observed. In spite of the species Haddadus binotatus being assigned to the not defined pattern, a male was observed vocalizing in March.

The species composition of FLOE Uaimií was most similar to other conservation units in the municipality of Ouro Preto (PE Itacolomi and EE Tripuí) which were also similar to Serra do Ouro Branco. The group formed by them has showed greater similarity with the RPPN Serra do Caraça. All these locations are in the Quadrilátero Ferrífero region, forming a separate group in the similarity dendrogram (Figure 4A). Two other mountainous regions in the MMR, the PESB and PARNA Caparaó, are similar regarding the anurans composition and they form a group with the Quadrilátero Ferrífero studied areas. The PE Ibitipoca, also in the MMR, formed an isolated branch, indicating that its species composition is different from that found in the other locations. The PARNA Cipó, in the EMR, was the location with the lowest similarity to the study area (Figures 4A and 4B).

\section{DISCUSSION}

The 36 species recorded in FLOE Uaimií correspond to $50 \%$ of the anurofauna known in the Quadrilátero Ferrífero region, situated in EMR, Minas Gerais state (Leite et al. 2008). The species richness of this conservation unit is only surpassed by Serra do Ouro Branco, with 47 species (São
Pedro and Feio 2011), and RPPN Serra do Caraça, with 43 species (Canelas and Bertoluci 2007). The recording of the species Hylodes babax represents the first record for the Quadrilátero Ferrífero region (Pirani et al. 2010).

The great richness of amphibian species associated with the EMR is due not only to its large area and high longitudinal and altitudinal amplitude, but certainly to the existence of a complex and intricate relationship between this historical and ecological formation and its adjacent biomes, the Cerrado and the Atlantic Forest (Leite et al. 2008). The EMR has a large environmental heterogeneity, presenting a mosaic of habitats from open areas to forests, providing a high resources variety, which has also been shown in other studies (Pedralli et al. 2001, Canelas and Bertoluci 2007, São Pedro and Feio 2010, São Pedro and Feio 2011). According to Rapini et al. (2008) and Versieux et al. (2008), the same pattern of great richness is observed for the flora of the rocky meadows of the EMR which also presents a high endemism rate.

Among the study sites, the Brejo da Estrada (P1) was the richest environment, housing 14 species. Cardoso et al. (1989) and Conte and RossaFeres (2006) highlighted spatial heterogeneity as a determinant of the environment richness. The amount of microhabitats with substrates for male calling activity available in each environment can be a determining factor for differentiating the richest site. Although we have not quantified, the P1 seems to be the sampled environment that presented the largest number of microhabitats.

The Cachoeira de São Bartolomeu rivulet (R2) presented lower richness, with only eight species, which may be related to the high flow of people in the area compared to the others study sites, due to the presence of a waterfall and an oratory dedicated to Saint Bartholomew. The Riacho do Alojamento (R1) and Brejo do Campo Rupestre (P2) presented the lowest richness, with seven species. Other studies show that temporary environments attract 


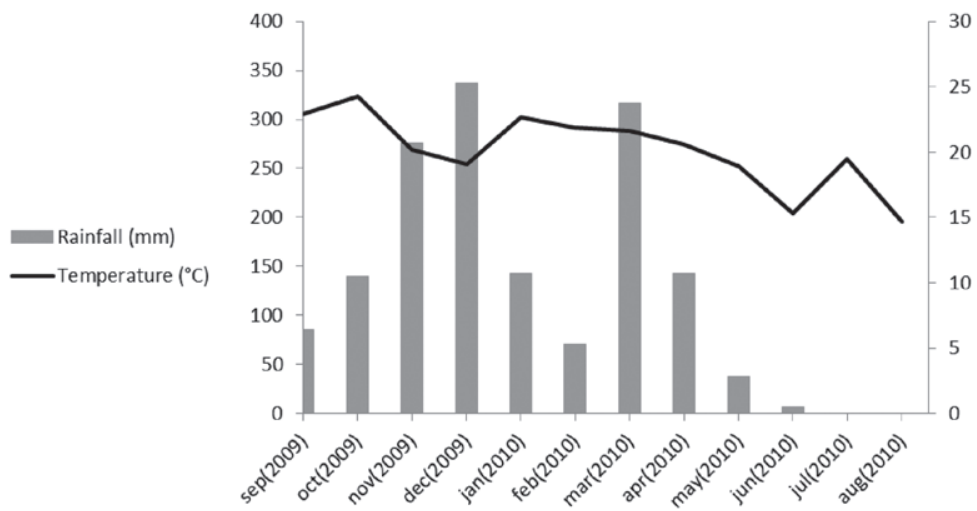

\begin{tabular}{|c|c|c|c|c|c|c|c|c|c|c|c|c|c|}
\hline & Sep & Oct & Nov & Dec & Jan & Fev & Mar & Apr & May & Jun & Jul & Aug & PR \\
\hline Aplastodiscus arildae & & & & & & & & & & & & $\mathrm{T}$ & $\mathrm{C}$ \\
\hline Aplastodiscus cavicola & & & & & & & & & & & & & $\mathrm{P}$ \\
\hline $\begin{array}{l}\text { Bokermannohyla sp. } \\
\text { (gr. circumdata) }\end{array}$ & & $\mathrm{F}$ & & & $\mathrm{F}$ & $\mathrm{T}$ & $\mathrm{T}$ & & $\mathrm{Y}, \mathrm{T}$ & $\mathrm{Y}, \mathrm{T}$ & & Y & ND \\
\hline Dendropsophus minutus & & & & & & & & & & & & & ND \\
\hline Elachistocleis cesarii & & $\mathrm{J}$ & & & & & & & & & & & $?$ \\
\hline Haddadus binotatus & & $\mathrm{Iv}$ & $\mathrm{Iv}$ & $\mathrm{Iv}$ & $\mathrm{F}, \mathrm{Y}$ & $\mathrm{Iv}$ & & Iv & & & & Iv & ND \\
\hline Hypsiboas albopunctatus & & & & & & & & & & & & & ND \\
\hline Hypsiboas faber & & & & & & & & & & & & & ND \\
\hline Hypsiboas polytaenius & & $\mathrm{T}$ & $\mathrm{T}$ & & $\mathrm{T}$ & $\mathrm{T}$ & $\mathrm{T}$ & $\mathrm{T}, \mathrm{Y}$ & $\mathrm{T}$ & $\mathrm{T}$ & $\mathrm{T}$ & $\mathrm{T}$ & $\mathrm{C}$ \\
\hline Ischnocnema izecksohni & $\mathrm{Y}$ & & $\mathrm{F}$ & & & Iv & Iv & Iv, Y & $\mathrm{Y}$ & $\mathrm{Y}$ & & & $\mathrm{P}$ \\
\hline Ischnocnema juipoca & & & & & & & & & & & & & $\mathrm{P}$ \\
\hline Leptodactylus cunicularius & & & $\mathrm{T}$ & $\mathrm{T}$ & $\mathrm{T}$ & & & & & & & & $\mathrm{P}$ \\
\hline Leptodactylus furnarius & & & & & $\mathrm{Iv}$ & $\mathrm{Iv}$ & & & & & & & $\mathrm{P}$ \\
\hline Leptodactylus fuscus & & & & & & & & & & & & & $\mathrm{P}$ \\
\hline Phasmahyla jandaia & & & & & & Iv & & & & & & & $?$ \\
\hline Phyllomedusa burmeisteri & & & & & & & & & & & & & $\mathrm{P}$ \\
\hline Physalaemus cuvieri & & $\mathrm{A}, \mathrm{S}$ & S & & & & & & & & & & $\mathrm{P}$ \\
\hline Proceratophrys boiei & & & & & & $\mathrm{T}$ & $\mathrm{T}$ & & & & & & $\mathrm{O}$ \\
\hline Pseudopaludicola serrana & & & $\mathrm{T}$ & & & & & & & & & & $\mathrm{P}$ \\
\hline Rhinella pombali & $\mathrm{T}$ & $\mathrm{Iv}$ & & & $\mathrm{Iv}$ & & & $\mathrm{Iv}$ & & & & & ND \\
\hline Rhinella rubescens & & Iv & & & & & & & & & & & ND \\
\hline Scinax sp. (aff. perereca) & & & & & & & & & & & & & $\mathrm{P}$ \\
\hline Scinax luizotavioi & & & & & & $\mathrm{T}$ & $\mathrm{T}$ & $\mathrm{T}$ & $\mathrm{T}$ & $\mathrm{T}$ & $\mathrm{T}$ & $\mathrm{T}$ & $\mathrm{Se}$ \\
\hline Vitreorana uranoscopa & & $\mathrm{A}$ & $\mathrm{S}$ & $\mathrm{S}$ & & & & & Iv & & & & $\mathrm{P}$ \\
\hline $\mathrm{N}$ spp in call. act. & 4 & 12 & 15 & 13 & 7 & 4 & 3 & 2 & 2 & 2 & 3 & 4 & \\
\hline $\mathrm{N}$ spp recorded & 5 & 17 & 16 & 14 & 11 & 10 & 7 & 5 & 5 & 5 & 3 & 6 & \\
\hline
\end{tabular}

Iv: individuals viewed, without emitting vocalization S: spawning, T: tadpoles; A: amplexus; Y: young and F: female. RP (reproduction pattern): C, continuous; P, prolonged; Se, seasonal; O, opportunistic; ND, not defined.

Figure 3 - Monthly rainfall (bars), average monthly temperature (line) and annual pattern of reproductive activity of 24 anuran species sampled in FLOE Uaimií (Ouro Preto, MG), from September 2009 to August 2010. 

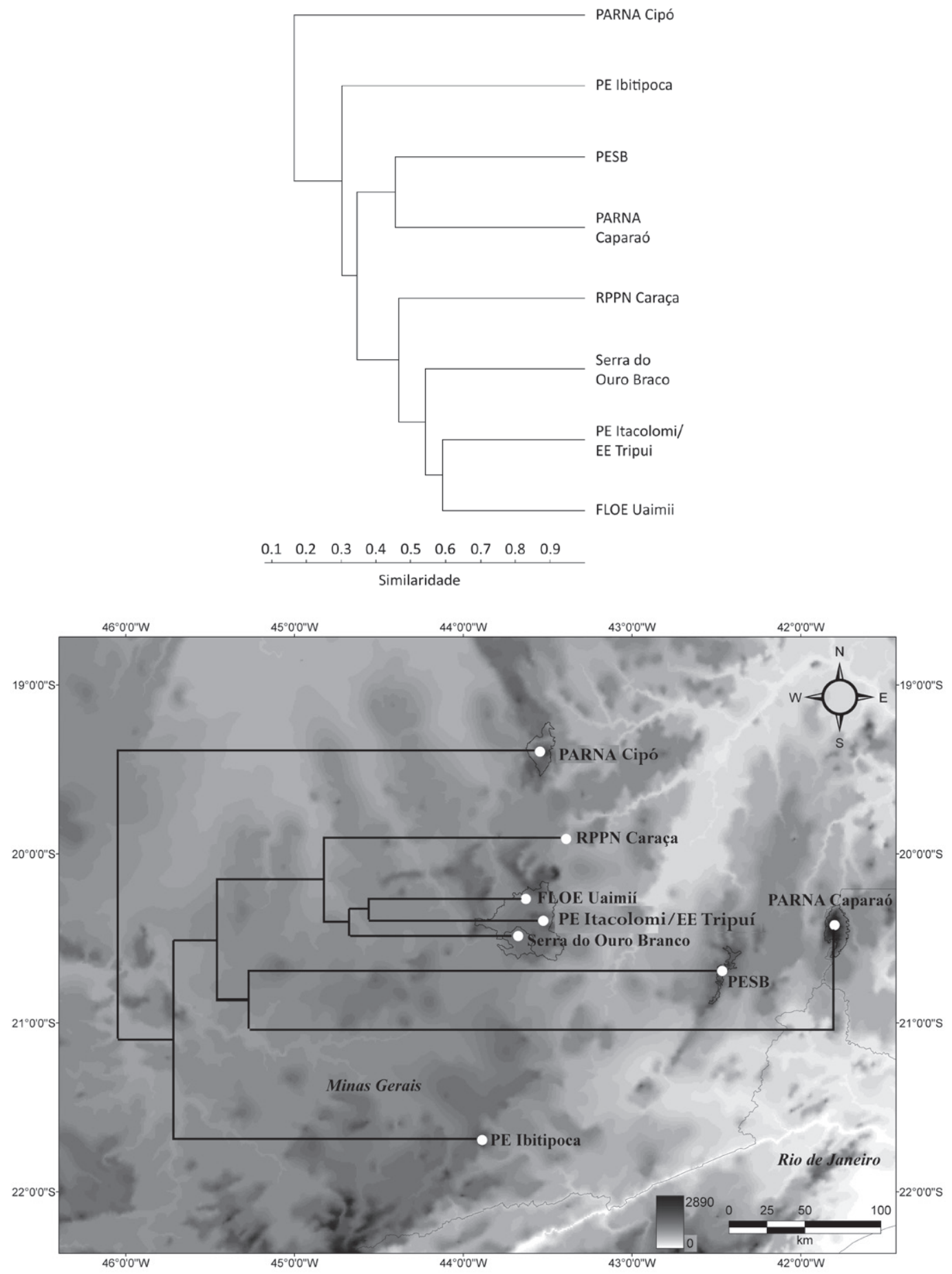

Figure 4 - (A) Similarity between localities and (B) Map of the dendrogram in overlapping areas of central-south and southeastern Minas Gerais state, Brazil: FLOE Uaimií (present study), Serra do Ouro Branco (São Pedro and Feio 2011), Parque Estadual do Itacolomi and Estação Ecológica do Tripuí (PE Itacolomi/EE Tripuí) (Pedralli et al. 2001), Parque Nacional da Serra do Cipó (PARNA Cipó) (Eterovick and Sazima 2004), Reserva Particular do Patrimônio Natural Serra do Caraça (RPPN Caraça) (Canelas and Bertoluci 2007), Parque Estadual Serra do Brigadeiro (PESB) (Moura et al. 2012), Parque Estadual do Ibitipoca (PE Ibitipoca) (Cruz et al. 2009) and Parque Nacional da Serra do Caparaó (PARNA Caparaó) (V.K. Verdade et al., unpublished data). Cophenetic correlation coefficient $=0.9213$ 
more species due to the reduced amount or absence of tadpoles predators (Alford 1999, Bertoluci and Rodrigues 2002). This is not observed at P2 in FLOE Uaimií.

The majority of the FLOE Uaimií anurans followed a seasonal pattern of calling activity in which the species vocalized during the warmer and wetter months of the year. This same pattern was noted in studies conducted in other Brazil regions (Heyer et al. 1990, Rossa-Feres and Jim 1994, Pombal Jr 1997, Bertoluci 1998, Bernarde and Anjos 1999, Bernarde et al. 1999, Vasconcelos and Rossa-Feres 2005, Canelas and Bertoluci 2007, São Pedro and Feio 2010). In tropical regions, the rain seems to be the main factor regulating the anurans reproductive activities (Aichinger 1987, Heyer 1973), not only because of the vulnerability of these animals to desiccation, but also because it is the rain that determines the viability and duration of their reproductive sites (Gottsberger and Gruber 2004).

Some species like Aplastodiscus arildae and Hypsiboas polytaenius had a continuous vocalization period. The same pattern was observed for the A. arildae in Parque das Mangabeiras, in the municipality of Belo Horizonte (Carvalho et al. 2006) and at RPPN Serra do Caraça (Canelas and Bertoluci 2007) and for H. polytaenius at this last locality and at Serra do Ouro Branco (Canelas and Bertoluci 2007, São Pedro and Feio 2010, respectively).

It was not possible to define the vocalization pattern for some species, such as D. minutus, $H$. albopunctatus, and $H$. faber, because they were registered only once during the study period at FLOE Uaimií. However, the three species are very abundant in other studied areas within the Quadrilátero Ferrífero region and were registered almost all the year, presented a higher density of calling males during the rainy season (Grandinetti and Jacobi 2005, Canelas and Bertoluci 2007, São Pedro and Feio 2010).
Other anuran species can present explosive reproductive patterns (sensu Wells 1977), so they call for only a short period. Field activities did not coincide with the nights when they vocalized (Toledo et al. 2003). This may be the case for the species Elachistocleis cesarii, which demonstrated explosive reproductive patterns in Fazenda Intervales, state of São Paulo (Bertoluci 1998) and RPPN Serra do Caraça (Canelas and Bertoluci 2007).

Three species of the genus Leptodactylus, from the L. fuscus species group (sensu Heyer 1978), occurring in P2, had overlapping vocalization periods in the rainy season, as observed in other studies (Canelas and Bertoluci 2007, São Pedro and Feio 2010). Apparently, they demonstrated a different spatial distribution of calling sites on the body water edge. Leptodactylus fuscus was found on the soil, L. furnarius within the grasses, and L. cunicularius among the rocks. However, the indication of a spatial partitioning could be speculative in this case.

The studied communities at localities that are included at the Quadrilátero Ferrífero region (FLOE Uaimií, PE Itacolomi/EE Tripuí, Serra do Ouro Branco, and RPPN Serra do Caraça) form a cluster in the similarity dendrogram. According to Leite et al. (2008), and within what is currently known, it is possible to recognise three major relief units along the EMR, based on the endemic anurans species distribution, and one of which is at the Quadrilátero Ferrífero. The present study confirms this proposal, because the most similar anuran communities are from this unit. The dissimilarity verified in this study among the PARNA Cipó and others studied areas from the EMR could be also explained by the proposal of Leite et al. (2008). The second proposed unit begins at Serra do Cipó and continues to mountains in the north of the Minas Gerais state. One endemic species of the EMR could exemplify this fact, Bokermannohyla martinsi, whose distribution is related only to the Quadrilátero Ferrífero unit (Leite et al. 2008). 
Although, it is important to point out that most studies conducted at PARNA Cipó are related to the rocky meadows complex and on the western slopes of the mountain range bordering the São Francisco river basin (Madeira et al. 2008). According to Madeira et al. (2008), the Atlantic Forest portion located in Serra do Cipó is poorly sampled for various species groups, including amphibians.

The Cerrado and Atlantic Forest biomes influence on the EMR is an important factor for understanding the current observed distribution of these amphibian species (Leite et al. 2008). The EMR not only separates the coastal hydrographic basins from the inland basins, but also the Cerrado (in the west) and Atlantic Forest biomes (in the east/southeast) and it acts as a barrier for many species typical of these different phytogeographic formations (Leite et al. 2008). Thus, the western EMR acts as the occurrence limit of species or even genera (e.g. Phasmahyla, Thoropa, Crossodactylus, Hylodes and Cycloramphus) that have the centre of their occurrence areas in the Atlantic Forest. The same can be observed for species typical from Cerrado biome (e.g. Ameerega flavopicta and Physalaemus centralis), whose geographic distribution does not extend further than the western slope of the EMR (Leite et al. 2008).

Species with restricted distributions, related physiologically, occupying the same environmental physiognomy in different mountain ranges (Espinhaço and Mantiqueira), suggest biogeographic homologies and raise speculations about the influence of the geomorphologic evolution in the anurans speciation patterns (Nascimento et al. 2005, Cruz and Feio 2007). Species with distribution in both the EMR and MMR (e.g. Hylodes babax Pirani et al. 2010; and Scinax luizotavioi - Moura et al. 2012; Physalaemus maxinus and Dendropsophus giesleri - São Pedro and Feio 2011; Ischnocnema izecksohni - Taucce et al. 2012) could explain an anuran fauna similarity of PESB and PARNA Caparaó with the Quadrilátero Ferrífero clade.
The PE Ibitipoca is composed of quartzite, forming a prominent elevated lowland hill (Cruz et al. 2009). Its vegetation is composed mainly of montane meadows at higher altitudes (from 1,050 to $1,784 \mathrm{~m}$ ), patches of rocky meadows, and forest formations (Cruz et al. 2009). Even though the continuous altimetry provides some form of connection between the EMR and MMR, differences in the geological formations and relationships to the biogeographic domains provide PE Ibitipoca with some environmental peculiarities, making it less similar to FLOE Uaimií (Cruz et al. 2009).

Although the most part of the amphibians species registered in this study have showed wide geographical distribution, the FLOE Uaimií anuran community include species from both mountain complex, the EMR and MMR. Endemic distribution of anurans species emphasizes the needing of strategies to conserve the FLOE Uaimií and also the EMR.

\section{ACKNOWLEDGMENTS}

We would like to thank everyone who helped us during the fieldwork. We are grateful to Paulo C. A. Garcia and Emanuel Texeira da Silva (ETS) for valuable suggestions on a previous version of the manuscript. ETS for his help in the statistical analysis. Mário Moura and Diego Santana for construction of the map. All residents of São Bartolomeu for their logistical support. RMP thanks Coordenação de Aperfeiçoamento de Pessoal de Nível Superior (CAPES) and Fundação Artur Bernardes (FUNARBE) for financial support. LBN thanks Conselho Nacional de Desenvolvimento Científico e Tecnológico (CNPq- Process 479457/2012-03), and Fundação de Amparo à Pesquisa do Estado de Minas Gerais (FAPEMIG, Process APQ00683-12). RNF thanks for Conselho Nacional de Desenvolvimento Científico e Tecnológico (CNPq) for the productivity fellowship conceded. 


\section{RESUMO}

O estudo apresenta a riqueza de espécies, distribuição temporal e atividade reprodutiva dos anfíbios anuros da Floresta Estadual do Uaimií situado na região do Quadrilátero Ferrífero, município de Ouro Preto, estado de Minas Gerais, Brasil. Foram realizadas campanhas mensais no período de Setembro de 2009 a Agosto de 2010. Foram registradas 36 espécies de anuros, distribuídas entre 10 famílias. Maior riqueza de espécies foi verificada em uma área de riacho permanente em mata secundária. A maioria das espécies de anuros apresentou um padrão de atividade de vocalização sazonal, principalmente relacionado à estação chuvosa. A composição de espécies de anuros da FLOE Uaimií é similar a de outras áreas estudadas na região do Quadrilátero Ferrífero.

Palavras-chave: anfíbios, Serra do Espinhaço, inventário, atividade reprodutiva.

\section{REFERENCES}

AICHINGER M. 1987. Annual activity patterns of anurans in a seasonal Neotropical environment. Oecol 71(4): 583-592.

ALFORD RA. 1999. Ecology: Resource use, competition and predation. In: Mcdiarmid RW and Altig R (Eds), Tadpoles. The biology of anuran larvae. The University of Chicago Press, Chicago, USA, p. 240-247.

Alvarenga MA, BEZERRA DA SILVA JE AND NunES PS. 1997. Unidades de Relevo. In: Instituto Brasileiro de Geografia e Estatística - IBGE. Recursos Naturais e Meio Ambiente: uma visão do Brasil. $2^{\text {a }}$ ed., Rio de Janeiro, IBGE, Departamento de Recursos Naturais e Estudos Ambientais, p. 51-73.

BERNARDE PA AND ANJos L. 1999. Distribuição espacial e temporal da anurofauna no Parque Estadual Mata dos Godoy, Londrina, Paraná, Brasil (Amphibia: Anura). Comun Mus Ciênc Tecnol PUCRS 12: 127-140.

BERnARde PS, KoKUBUm MCN, Machado RA AND ANJOS L. 1999. Uso de habitats naturais e antrópicos pelos anuros em uma localidade no estado de Rondônia, Brasil (Amphibia: Anura). Act Amaz 29: 555-562.

BERTOLUCI J AND RODRIGUES MT. 2002. Utilização de habitats reprodutivos e micro-habitats de vocalização em uma taxocenose de anuros (Amphibia) da Mata Atlântica do sudeste do Brasil. São Paulo. Pap Avul Zool 42(11): 287-297.

BertoluCi JA. 1998. Annual patterns of breeding activity in Atlantic Rainforest anurans. J Herpetol 32: 607-611.

Canelas MAS AND Bertoluci J. 2007. Anurans of the Serra do Caraça, southeastern Brazil: species composition and fenological patterns of calling activity. Porto Alegre. Iheringia Sér Zool 97(1): 21-26.
CARdoso AJ, ANdrade GV AND HaddAd CFB. 1989. Distribuição espacial em comunidades de anfíbios (Anuros) no Sudeste do Brasil. Rev Bras Bio 49(1): 241-249.

CARDoso AJ AND HADDAD CFB. 1992. Diversidade e turno de vocalização de anuros em comunidade neotropical. Acta Zool Lit 41: 93-105.

CARVAlHO JR RR, GALDINO CAB AND NASCIMENTO LB. 2006. Notes on the courtship behavior of Aplastodiscus arildae (Cruz and Peixoto, 1985) at an urban forest fragment in Southeastern Brazil (Amphibia, Anura, Hylidae). Arq Mus Nac Rio Jan 64(3): 247-254.

Conte CE AND Rossa-Feres DC. 2006. Diversidade e ocorrência temporal da anurofauna (Amphibia, Anura) em São José dos Pinhais, Paraná, Brasil. Rev Bras Zool 23(1): 162-175.

CONTE CE AND RosSA-FERES DC. 2007. Riqueza e distribuição espaço-temporal de anuros em um remanescente de Floresta de Araucária no sudeste do Paraná. Rev Bras Zool 24(4): 1025-1037.

CRUz CAG AND Feio RN. 2007. Endemismos em anfíbios em áreas de altitude na Mata Atlântica no sudeste do Brasil. In: Nascimento LB and Oliveira ME (Eds), Herpetologia no Brasil II. Soc Bras Herpet, p. 117-126.

Cruz CAG, Feio RN AND CARAmaschi U. 2009. Anfíbios do Ibitipoca. Belo Horizonte: Bicho do Mato Ed., 132 p.

Drummond GM, Martins CS, Machado ABM, SEBAio FA AND ANTONINI Y. 2005. Biodiversidade em Minas Gerais: um Atlas para sua Conservação. $2^{\mathrm{a}}$ ed., Belo Horizonte. Fundação Biodiversitas, 222 p.

ETEROVICK PC. 2003. Distribution of anuran species among montage streams in south-eastern Brazil. J Trop Ecol 19: 219-228.

ETEROVICK PC AND SAZIMA I. 2000. Structure of an anuran community in a montane meadow in southeastern Brazil: effects of seasonality, habitat, and predation. Amph-Rept 21(4): 439-461.

Eterovick PC AND SAzima I. 2004. Anfíbios da Serra do Cipó, Minas Gerais - Amphibians from the Serra do Cipó, Minas Gerais. $1^{\text {a }}$ ed., Belo Horizonte. Ed. PUC Minas $1,152 \mathrm{p}$.

GonTiJo BM. 2009. Uma geografia para a Cadeia do Espinhaço. Megadiv 4(1-2): 7-14.

GotTsBerger B AND GRUBER E. 2004. Temporal partitioning of reproductive activity in a neotropical anuran community. J Trop Ecol 20: 271-280.

GRANDINETTI L AND JACOBI CM. 2005. Distribuição estacional e espacial de uma taxocenose de anuros (Amphibia) em uma área antropizada em Rio Acima - MG. Instituto de Ciências Biológicas - UFMG. Belo Horizonte, MG. Lund 6(1): 21-28.

HEYER WR. 1973. Ecological interactions of frog larvae at a seasonal tropical location in Thailand. J Herpet 7: 337-361.

HEYER WR. 1978. Systematics of the fuscus group of the genus Leptodactylus (Amphibia, Leptodactylidae). Natur Hist Mus Los Angeles County Sci Bul 29: 1-85. 
Heyer WR, RAND AS, CRuZ CAG, PEIXoto OL AND Nelson CE. 1990. Frogs of Boracéia. Arq Zool 31(4): 231-410.

IEF - Instituto EstaduAL DE Florestas. 2008. Available from: $<$ http://www.ief.mg.gov.br/index.php?option=com content $\&$ task $=$ view\&id=633\&Itemid $=139>$. Access: $2 \overline{5}$ march 2012.

KÖPPEN W. 1918. Klassification der klimate nach temperatur, Niederschlag und Jahreslauf. Petermanns Geogr Mitteilungen 64: 193-203.

KREBS CJ. 1999. Ecological Methodology. Menlo Park: Addison Wesley Longman, $620 \mathrm{p}$.

LACERDA JVA, Assis B, SANTANA DJ AND Feio RN. 2009. Anurans in bromeliads, Parque Estadual da Serra do Brigadeiro, state of Minas Gerais, southeastern Brazil. Check List 5(4): 800-806.

LEITE FSF, JunCÁ FA AND ETEROVICK PC. 2008. Status do conhecimento, endemismo e conservação de anfíbios anuros da Serra do Espinhaço, Brasil. Megadiv 4(1-2): 158-176.

MADEIRA JA, RiBEIRO KT, OLIVEIRA MJR, NASCIMENTO JS AND PAIVA CL. 2008. Distribuição espacial do esforço de pesquisa biológica na Serra do Cipó, Minas Gerais: subsídios ao manejo das unidades de conservação da região. Megadiv 4(1-2): 257-271.

Moura MR, Motta AP, Fernandes VD AND Feio RN 2012. Herpetofauna da Serra do Brigadeiro, um remanescente de Mata Atlântica em Minas Gerais, sudeste do Brasil. Biot Neot 12(1): 1-27.

NAscimento LB, Miranda ACL And Balstaedt TAM. 1994. Distribuição estacional e temporal de anfíbios anuros da Área de Proteção da Captação da Mutuca (Nova Lima, MG). Bios 2(2): 5-12.

NASCIMENTO LB, WACHLEVSCKI M AND LEITE FSF. 2005. Anuros. In: Silva AC, Pedreira LCVSF and Abreu PAA (Eds), Serra do Espinhaço Meridional: paisagens e ambientes. Belo Horizonte. O Lutador, 272 p.

Pedralli G, Guimarães-Neto AS AND TeiXeira MCB. 2001. Diversidade de anfíbios na região de Ouro Preto. Ciência Hoje 30(178): 70-76.

PIANKA ER. 1973. The Structure of Lizard Communities. Ann Rev Ecol and Syst 4: 53-74.

PIRANi RM, MÂngIa S, SANTANA DJ, Assis B AND FEIO RN. 2010. Rediscovery, distribution extension and natural history notes of Hylodes babax (Anura, Hylodidae) with comments on Southeastern Brazil Biogeography. SAJH 5(2): 83-88.

POMBAL JR JP. 1997. Distribuição espacial e temporal de anuros (amphibia) em uma poça permanente na Serra de Paranapiacaba, Sudeste do Brasil. Rev Bras Biol 57(4): 583-594.
PYRON RA AND WIENS JJ. 2011. A large-scale phylogeny of Amphibia including over 2800 species, and a revised classification of extant frogs, salamanders, and caecilians. Mol Phyl Evol 61(2): 543-583.

RAPINI A, Ribeiro PL, LAMBERT S AND PIRANI JR. 2008. A flora dos campos rupestres da Cadeia do Espinhaço. Megadiv 4(1-2): 15-23.

ROSSA-FERES DC AND JIM J. 1994. Distribuição sazonal em comunidades de anfíbios anuros na região de Botucatu, São Paulo. Rev Bras Biol 54(2): 323-334.

SÁ Junior A, De CARVAlho LG, DA Silva FF AND Alves MC. 2011. Application of the Köppen classification for climatic zoning in the state of Minas Gerais, Brazil. Theor Appl Climatol 108(1-2): 1-7.

SÃo PEDRO VA AND FEIO RN. 2010. Distribuição espacial e sazonal de anuros em três ambientes na Serra do Ouro Branco, extremo sul da Cadeia do Espinhaço, Minas Gerais, Brasil. Biot 23(1): 143-154.

São Pedro VA AND FeIo RN. 2011. Anuran species composition from Serra do Ouro Branco, southernmost Espinhaço Mountain Range, state of Minas Gerais, Brazil. Check List 7(5): 671-680.

SILVANO DL AND SEGALLA MV. 2005. Conservação de anfíbios no Brasil. Megadiv 1(1): 79-86.

TAUCCE PPG, LeITE FSF, SANTOS PS, FEIO RN AND GARCIA PCA. 2012. The advertisement call, color patterns and distribution of Ischnocnema izecksohni (Caramaschi and Kisteumacher, 1989) (Anura, Brachycephalidae). Pap Avul Zool 52(9): 111-119.

Toledo LF, ZINA J AND HADDAD CFB. 2003. Distribuição espacial e temporal de uma comunidade de anfíbios anuros do município de Rio Claro, São Paulo, Brasil. Hol Envirom 3(2): 136-149.

VAsCONCELos TS AND RossA-Feres DC. 2005. Diversidade, distribuição espacial e temporal de anfíbios anuros (Amphibia: Anura) na região noroeste do estado de São Paulo, Brasil. Biota Neotropica, 5 (2). Available from: $<$ http://www.biotaneotropica. org.br/ v5n2/pt/ abstract?art icle+BN01705022005>. Access: 30 January 2012.

VERSIEUX LM, WENDT T, LOUZADA RB AND WANDERLEY MGL. 2008. Bromeliaceae da Cadeia do Espinhaço. Megadiv 4(1-2): 126-138.

VIANA PL AND FILGUEIRAS TS. 2009. Inventário e distribuição geográfica das gramíneas (Poaceae) na Cadeia do Espinhaço, Brasil. Megadiv 4(1-2): 99-116.

WELLS KD. 1977. The social behaviour of anuran amphibians. Animal Behaviour, p. 666-693. 